\title{
Nauczanie języka greckiego \\ studentów teologii - omówienie metod \\ i zakresu materiału na przykładzie lektoratów \\ prowadzonych na Uniwersytecie Papieskim Jana Pawła II w Krakowie
}

\section{Lektorat języka greckiego na Wydziale Teologicznym UPJPII - założenia edukacyjne}

Na Wydziale Teologicznym Uniwersytetu Papieskiego Jana Pawła II w Krakowie zajęcia z języka greckiego prowadzone są na specjalności teologia kapłańska (w wymiarze jedna godzina tygodniowo przez jeden semestr) oraz teologia katechetyczno-pastoralna (przez dwa semestry po jednej godzinie tygodniowo). W obydwu przypadkach lektorat ten kończy się uzyskaniem zaliczenia $\mathrm{z}$ oceną i został on pomyślany jako kurs propedeutyczny do dalszej nauki języka greckiego dla osób, które ze względu na wybierane seminarium i temat pracy magisterskiej będą zobligowane do kontynuacji edukacji językowej w tym zakresie.

Celem kursów jest zatem zapoznanie studentów:

- $\quad \mathrm{z}$ alfabetem greckim przy uwzględnieniu różnic w tekście pisanym i drukowanym, 
- z zasadami pisania i czytania (umiejscowienie liter w linii, użycie różnych czcionek),

- ze znakami interpunkcyjnymi,

- z historią języka greckiego,

- z podstawowymi wiadomościami gramatycznymi.

W związku z tym materiał przewidziany do zrealizowania podczas lektoratu dla słuchaczy specjalności teologia kapłańska obejmuje następujące zagadnienia:

- pochodzenie, historia i dialekty języka greckiego,

- alfabet i dyftongi (właściwe, niewłaściwe),

- podstawowe nazewnictwo związane $\mathrm{z}$ akcentowaniem,

- zasady czytania i znaki interpunkcyjne,

- podstawowe modlitwy w języku greckim,

- koniugacje (nomenklatura koniugacyjna, podział na koniugacje indicativus, imperativus, infinitivus praesentis activi czasowników koniugacji I oraz czasownika „być”),

- deklinacja (nazewnictwo deklinacyjne, rzeczowniki i przymiotniki deklinacji II),

- technika tłumaczenia zdań pojedynczych,

- podstawowe informacje o składni ACI.

W związku z dwukrotnie większym wymiarem godzinowym lektoratu dla studentów specjalności katechetyczno-pastoralnej w ich przypadku realizowany materiał obejmuje dodatkowo:

- pronomina personalia et possesiva,

- rzeczowniki i przymiotniki deklinacji I (rodzaj żeński),

- składnię ACI w oparciu o wiadomości z języka łacińskiego,

- indicativus, infinitivus, imperativus praesentis medii-pasivi czasowników koniugacji I,

- verba deponentia,

- indicativus imperfecti activi $\mathrm{w}$ niezłożonych czasownikach koniugacji I,

- indicativus praesentis et imperfecti activi czasownika „być”.

Jak widać z powyższego wykazu, lektorzy języka greckiego w znacznym stopniu zakładają posiadanie przez studentów teologii znajomość podstawowych pojęć i zagadnień z zakresu gramatyki łacińskiej 
(np. składni ACI, orzeczenia imiennego). Zaś praktyka dydaktyczna wykazuje, że słuchacze ci - zwłaszcza w początkowym okresie edukacji są bardzo pozytywnie nastawieni do nauki kolejnego języka starożytnego. Cechuje ich raczej ciekawość aniżeli obawa przez nieznanym. Naukę alfabetu traktują jako zabawę w rysowanie liter, zaś ćwiczenia z czytania stanowią źródło wielu komicznych sytuacji. Notabene podobną postawę prezentują także studenci historii sztuki z Wydziału Historii i Dziedzictwa Kulturowego UPJPII, którzy - kierując się względami utylitarnymi - dobrowolnie zapisują się na kurs języka greckiego.

Poniżej przedstawiono przykłady ćwiczeń służących rozwijaniu umiejętności pisania oraz czytania w języku greckim, dostosowanych do profilu tematycznego i specyfiki kierunków studiów, dla których realizowany jest lektorat.

\section{Nauka alfabetu greckiego - propozycje ćwiczeń}

Prezentowane poniżej ćwiczenia mają na celu:

- zapoznanie z kształtami poszczególnych liter i ich nazwami,

- ukazanie różnic, jakie występują między kształtem litery pisanej i drukowanej,

- ułatwienie zapamiętania umiejscowienia liter w linii i ich kolejności w alfabecie,

- nabycie płynności w pisaniu zarówno liter dużych, jak i małych ${ }^{1}$.

Zad. 1. Wpisz obok nazw małe i duże litery greckie: alpha

beta

gamma

delta

epsilon

\footnotetext{
${ }^{1} \mathrm{~W}$ celu zapoznania się z techniką pisania liter greckich studenci mogą również obejrzeć filmy edukacyjne dostępne w internecie, które pokazują w wolniejszym tempie ruchy pióra.
} 


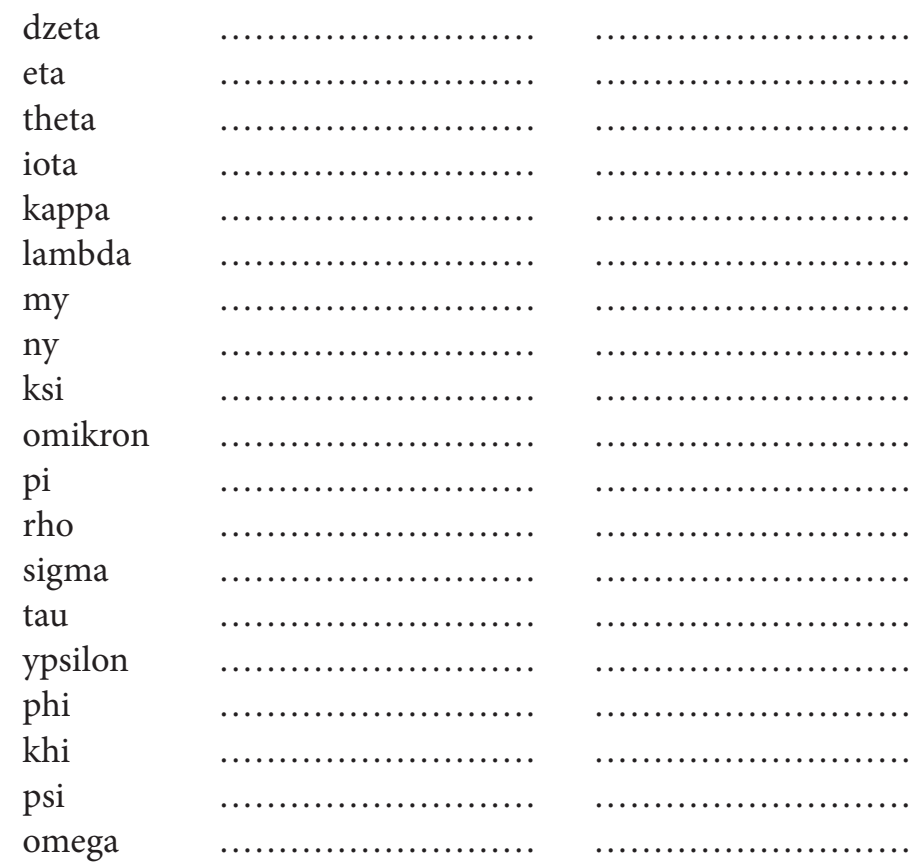

Zad. 2. Wstaw obok podanej litery kolejną $\mathrm{w}$ alfabecie: $\xi \ldots, \sigma \ldots$

$\gamma \ldots, \eta \ldots, \rho \ldots, \psi \ldots, \kappa \ldots, \mu \ldots$, o.., $\delta \ldots, \theta \ldots, \nu \ldots, \varphi \ldots, \beta \ldots, v \ldots, \chi \ldots$,

Zad. 3. Wstaw obok podanej litery literę poprzedzającą:

$\ldots \gamma, \ldots \eta, \ldots \rho, \ldots \psi, \ldots \kappa, \ldots \mu, \ldots o, \ldots \delta, \ldots \theta, \ldots \nu, \ldots \varphi, \ldots \beta, \ldots v, \ldots \chi$, $\ldots \xi, \ldots \sigma$.

Zad. 4. Wstaw po obu stronach litery poprzedzającą i kolejną:

$\ldots \beta \ldots, \ldots \rho \ldots, \ldots v \ldots, \ldots \lambda \ldots, \ldots \psi \ldots, \ldots \eta \ldots, \ldots \nu \ldots, \ldots \varphi \ldots, \ldots \chi \ldots$, $\ldots \varepsilon \ldots, \ldots \pi \ldots, \ldots \zeta \ldots$

Zad. 5. Podane wyrazy napisz dużymi literami (bez stawiania akcentów i przydechów): 


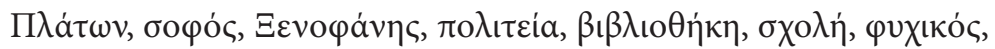

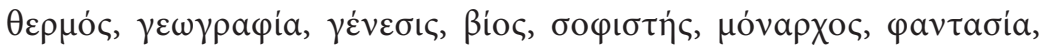

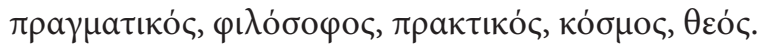

Zad. 6. Napisz transkrybowane wyrazy po grecku (w nawiasach zostały podane greckie zakończenia wyrazów, akcentowane samogłoski podkreślone, długie samogłoski pogrubione):

\begin{tabular}{|c|c|c|c|}
\hline rododendron & …............ & geograf (-os) & \\
\hline automat (-os) & $\ldots$ & uran (-os) & \\
\hline chaos & & synonim (-ymos) & \\
\hline historia & $\ldots$. & anomalia & \\
\hline fosfor (-os) & & demokracja(-tia) & \\
\hline pantera & $\ldots$ & hymn (-os) & \\
\hline teoria & $\ldots$ & katastrof-a (-e $)$ & \\
\hline Europ-a (-e) & $\ldots$ & hip(p)opotam (-os) & \\
\hline metafora & .............. & kanon & \\
\hline biblitheka (-e) & & theatr (-on) & \\
\hline
\end{tabular}

Zadania polegające na wstawianiu litery poprzedzającej i/lub kolejnej (tj. nr. 2, 3 i 4) mają dodatkowo na celu ułatwienie późniejszej pracy ze słownikiem. Bowiem w opinii studentów poważną trudność podczas tej czynności sprawia właśnie szybkie odnalezienie danej litery². Doskonaleniu tej umiejętności może również służyć ćwiczenie polegające na układaniu podanych rzeczowników i przymiotników w kolejności alfabetycznej.

\section{Nauka czytania - propozycje ćwiczeń}

Pierwszym etapem nauki czytania zapisów w języku greckim może być odcyfrowywanie brzmienia pojedynczych słów, które są tak dobrane,

\footnotetext{
${ }^{2}$ Na ile jest to żywotny problem, świadczy fakt, iż jeden ze studentów zadał sobie trud wykonania wykazu stron, na których kolejne litery znajdują się w każdym z dostępnych na zajęciach słowników.
} 
by kojarzyły się z terminami obecnymi w języku polskim (np. „diakon” gr. ठıákovos).

Dalsze doskonalenie umiejętności płynnego czytania w przypadku studentów teologii odbywa się w oparciu o teksty modlitw, które - po uprzednim przeczytaniu - słuchacze otrzymają także w postaci plików dźwiękowych, pozwalających im na samodzielne utrwalanie poprawnego brzmienia słów. Czytaniem, a w późniejszym okresie mówieniem z pamięci poznanych modlitw rozpoczynają się także każde kolejne zajęcia.

Natomiast ćwiczenie polegające na odczytywaniu przerysów inskrypcji starochrześcijańskich ${ }^{3}$ pozwala dodatkowo uświadomić studentom różnorodność form tekstów greckich, z którymi można się zetknąć, np.:
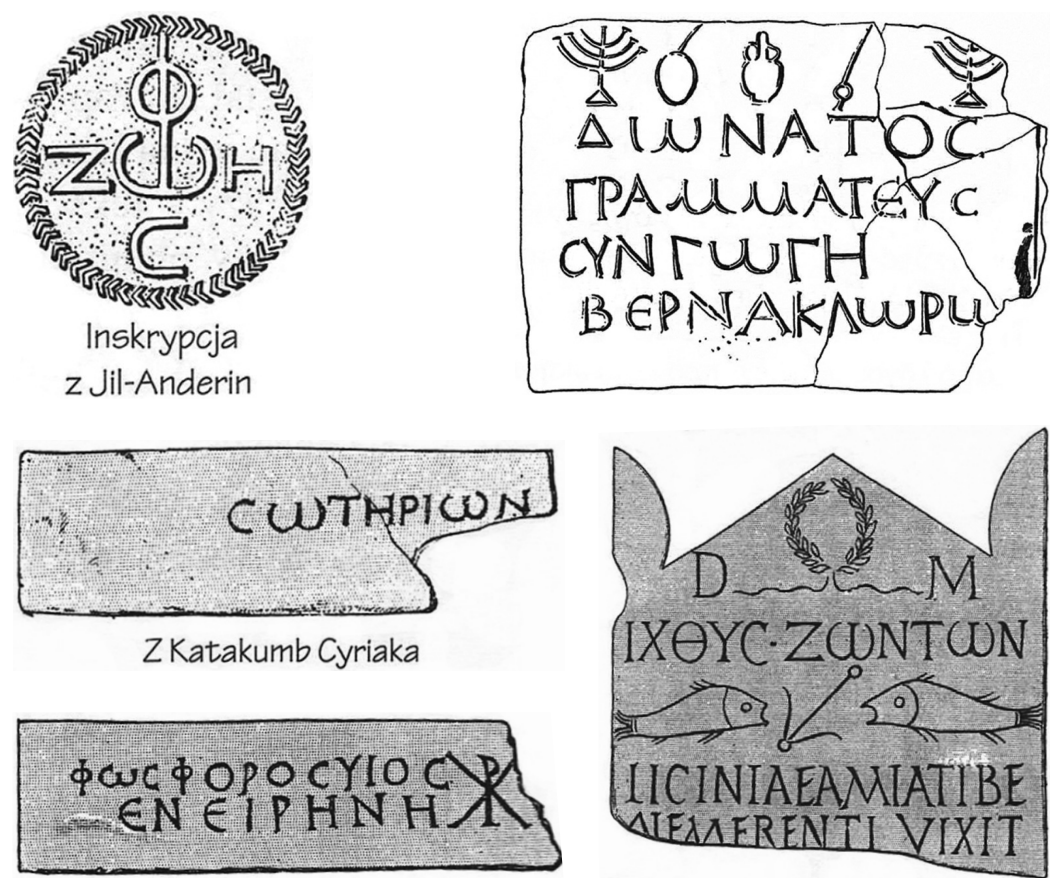

Z katakumb Cyriaka. Kim był Fosforos?

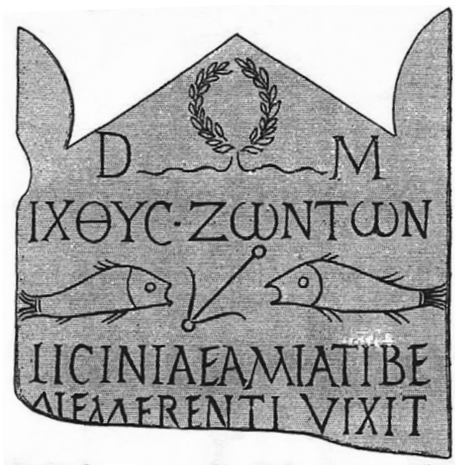

Epitafium rzymskie „Ryba żyjących”

3 Ilustracje zaczerpnięto z: K. Bardski, Język grecki Nowego Testamentu. Podręcznik, Warszawa 2000, s. 4, 15, 27, 46, 65. 
Także na etapie zapoznawania się z historią, pochodzeniem i ewolucją języka greckiego studenci mają możliwość ćwiczenia umiejętności czytania, gdy próbują zmierzyć się z oryginalnym zapisem pochodzącym ze stronicy kodeksu greckiego ${ }^{4}$, np.:

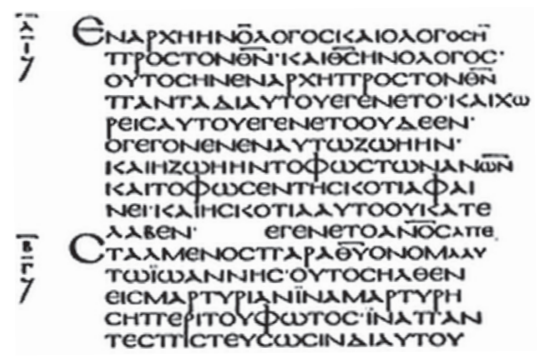

Na tak zbudowanym podłożu umiejętności czytania i pisania studenci przyswajają następnie podstawowe wiadomości dotyczące deklinacji i koniugacji w języku greckim. Na tym etapie stosowana jest metoda gramatyczno-tłumaczeniowa z wykorzystaniem - w miarę możliwości - oryginalnych fragmentów tekstów oraz nowoczesnych form przekazu.

\section{Bibliografia}

Bardski K., Język grecki Nowego Testamentu. Podręcznik, Warszawa 2000.

Korus A., Korus K., Hellenike Glotta. Podręcznik do nauki języka greckiego, Kraków 2009.

Szamocki G., Greka Nowego Testamentu. Intensywny kurs podstawowy, Pelplin 2004 .

\footnotetext{
${ }^{4}$ Ilustrację zaczerpnięto z okładki publikacji G. Szamocki, Greka Nowego Testamentu. Intensywny kurs podstawowy, Pelplin 2004.
} 


\section{Abstract}

The article discusses the organization of Greek language classes for the students of Catechetical and Pastoral Theology, as well as Theology of Priesthood at the Faculty of Theology of the Pontifical University of John Paul II in terms of the established educational goals and the class content. The author also presented her own sample exercises aimed at developing the skills of writing and reading in Greek, suitable for the thematic profile and character of the fields of study for which the language classes are intended.

Słowa kluczowe: język grecki, nauka czytania i pisania, lektorat dla studentów teologii

Keywords: Greek language, development of reading and writing skills, language classes for theology students 